\title{
O PAPEL DA/NA MÍDIA IMPRESSA NA FORMAÇÃO DO SUJEITO
}

\section{THE ROLE OF / IN PRINTED MEDIA TRAINING IN THE SUBJECT}

\author{
Cristiane Pereira de Morais e Sousa (UEMS)
}

\begin{abstract}
Resumo: Este artigo visa a analisar o discurso jornalístico, especialmente da mídia impressa, cujo objetivo é enfocar as relações de poder no discurso midiático, e detectar como o sujeito-jornalista, dentro de uma ordem, utiliza estratégias discursivas para estabelecer "várias verdades" de um único fato. A partir do dispositivo teórico da Análise do Discurso derivada de Pêcheux (1994), Foucault (2005) e a alguns estudiosos da mídia, selecionamos e analisamos alguns fragmentos oriundos do corpus de nossa pesquisa de mestrado (nas revistas Veja e Istoé) sobre o desarmamento 2005. Os meios de comunicação constroem, produzem sentidos, tornando-se instrumentos de poder, capazes de influenciar a forma de pensar e agir em sociedade. Portanto, analisar o discurso é interpretar os sujeitos falando e suas condições de produção, pois, os sentidos das palavras no discurso não são fixos, estáveis, são produzidos mediante os lugares ocupados pelos sujeitos em interlocução.
\end{abstract}

Palavras-chave: Análise do discurso. Mídia impressa. Sujeito. Sociedade.

\begin{abstract}
This article seeks to analyze the journalistic speech, especially of the media printed, whose objective is to focus the relationships of power in the speech of the media, and to detect as the subject-journalist, inside of an order, it uses discursive strategies to establish "several truths" of a single fact. From the device theoretical analysis of the speech derived from Pêcheux (1994) and Foucault (2005), and the some specialists of the media, we selected and we analyzed some fragments originating from of the corpus of our master's research (in the magazines Veja and Istoé) on the disarmament 2005. The communication means build, they produce senses, becoming instruments of power, capable to influence the form of to think and to act in society. Therefore, to analyze the speech is to interpret the subjects speaking and their production conditions, because, the senses of the words in the speech are not fixed, stable, they are produced by the busy places by the subjects in dialogue.
\end{abstract}

Keywords: Analysis of the speech. Media printed. Subject. Society.

\section{Introdução}

Atualmente, podemos dizer que a mídia é a principal formadora de opinião, pois induz a comportamentos e dita regras para que o indivíduo possa estar inserido na sociedade. Dito de outra forma, ele não se sentirá excluído se estiver bem informado, "antenado" com os acontecimentos, uma vez que ele precisa do "saber" doado pela mídia para "ser", ou, de certo modo, sobressair-se, autoafirmar-se, tanto profissional quanto pessoalmente.

Assim, é possível inferir como os meios de comunicação estão inseridos nas relações sociais, políticas e econômicas de uma sociedade. É importante ressaltar que, a sociedade contemporânea, cada vez mais, necessita de informações sobre os acontecimentos e, portanto, é inegável que os meios de comunicação têm uma influência enorme na sociedade. Eles constroem, produzem sentidos (e não apenas informam ou relatam fatos), tornando-se instrumentos de poder, capazes de influenciar a forma de pensar e agir em sociedade. Nas palavras do jornalista Hamilton Ribeiro, "a imprensa livre é o quarto poder de um país", referindo-se a acontecimentos sobre o jornalismo e a relação de poder que exerce, a ponto de os Poderes Legislativo, Executivo e Judiciário curvarem-se diante do poder da mídia (RIBEIRO, 1997, p. 97).

Ao analisarmos o discurso jornalístico, estamos refletindo sobre as informações que nos chegam diariamente. Isso é fundamental, haja vista os leitores serem bombardeados por inúmeras notícias e reportagens que são digeridas sem que haja reflexão sobre os efeitos de

\begin{tabular}{|l|l|l|l|l|l|}
\hline Interfaces da Educ. & Paranaíba & v. 1 & n. 2 & p. 28-43 & 2010 \\
\hline
\end{tabular}


sentido que são propagados.

Diante disso, neste artigo, apresentamos alguns aspectos de nossa pesquisa de mestrado acerca do discurso jornalístico, especialmente da mídia impressa, cujo objetivo é enfocar as relações de poder no discurso midiático, e detectar como o sujeito-jornalista, dentro de uma ordem, utiliza estratégias discursivas para estabelecer "várias verdades" de um único fato. Assim como, analisar o discurso do sujeito-leitor, como ele (sujeito/leitor/eleitor) é visto pela mídia e como a vê. Ou seja, o papel que a mídia impressa exerce sobre o sujeito.

Para tanto, selecionamos e analisamos quatro sequências discursivas oriundas de reportagens das revistas Veja e Istoé (acerca do desarmamento 2005). Abordamos, ainda, a "Seção Cartas", em ambas as revistas, a partir de oito recortes (quatro de cada revista) sobre o mesmo tema, a fim de mostrar e ratificar as sequências discursivas analisadas, e verificar a imagem que os leitores têm de suas revistas e como elas projetam-se para os leitores constituídos.

Para a análise dos dados, recorremos aos pressupostos teóricos da Análise do Discurso (AD) derivada da linha de Pêcheux (1994), Foucault (2005) e a alguns estudiosos da mídia. Trabalhamos com a análise e interpretação de textos da mídia, ocupando a função-leitor que observa discursivamente o processo de construção de sentidos dos textos. Destarte, interpretamos observando o confronto dos textos produzidos nos diferentes contextos, os sentidos, (des)construídos e reconstruídos nessa trajetória, bem como as condições de produção dos discursos.

\section{Sujeito}

O sujeito na $\mathrm{AD}$ deve, a princípio, ser compreendido como um sujeito que não é individual, porque enquanto ser humano, não é individualizado. Dito de outro modo, não se trata do indivíduo, da pessoa, como um ser empírico que tem existência particular, embora não se negue a existência real dos sujeitos que vivem em uma sociedade. Logo, ele deve ser considerado sempre como um sujeito social, não individualizado, mas apreendido em um espaço coletivo, ou seja, um sujeito que tem a existência em um espaço social e ideológico, em um determinado momento na história.

Dessa forma, o sujeito na $\mathrm{AD}$ não pode ser categorizado e posicionado em lugares definidos, visto que é determinado pela posição e lugar de onde enuncia, e o lugar que ocupa é determinante para ser sujeito do que diz. Portanto, não exerce um papel definitivo, porque se movimenta e se situa em diversas posições, constituindo-se pela/na heterogeneidade.

Orlandi (2005) postula que todo texto é heterogêneo em relação aos distintos materiais simbólicos (como imagem, som, grafia), às distintas formas de linguagem (oral, escrita, científica) e também quanto às posições do sujeito, que no discurso jornalístico (nosso objeto), são identificáveis, pois encontramos várias formações discursivas em um texto, as quais nele se organizam em torno de uma formação discursiva dominante.

Segundo Foucault (2005a, p. 61), a noção de discurso é "um conjunto em que podem ser determinadas a dispersão do sujeito e sua descontinuidade em relação a si mesmo. É um espaço de exterioridade em que se desenvolve uma rede de lugares distintos". Dessa maneira, o discurso é uma dispersão de textos, enquanto o texto é uma dispersão do sujeito.

No discurso jornalístico, o sujeito se subjetiva de diversas maneiras, constituindo-se uma dispersão de textos: os dos jornalistas, dos editores, dos fotógrafos, dos entrevistados, entre outros.

Zandwais (2005, p.146) reportando-se aos modos de subjetivação do sujeito em/de Pêcheux (1997), destaca: "um sujeito-enunciador que toma posições a partir do lugar que se reconhece como sujeito, e, portanto, se coloca em seu discurso como portador de uma

\begin{tabular}{|l|l|l|l|l|l|}
\hline Interfaces da Educ. & Paranaíba & v. 1 & n. 2 & p. 28-43 & 2010 \\
\hline
\end{tabular}


identidade que acredita ser objeto de sua livre opção". Vale destacar a questão do sujeitoenunciador, pois recorremos ao termo enunciador nas sequências discursivas analisadas nos discursos de Veja e Istoé: como enunciadores, tornando-se sujeitos às/de suas palavras.

Ao conceituar o sujeito em $\mathrm{AD}$, mais uma vez recorremos ao nosso objeto, o discurso jornalístico, que, por meio do sujeito-jornalista, produz o seu discurso. Esse sujeito, se questionado sobre o que escreveu, o motivo que o levou a usar determinada palavra em detrimento de outras, com certeza nos dirá que produziu sua matéria pensando em elaborar um texto objetivo, coeso, com a finalidade de informar seu leitor. Para ele, essa escolha é pessoal e consciente, baseada nas fontes de informação às quais teve acesso (cf. PRELLVITZ, 2006).

Assim, no que concerne ao jornalista, percebemos um profissional que se diz centrado, acreditando ser dono do seu dizer e de seu fazer, sujeito cujo perfil equivale ao:

[...] sujeito moderno - capitalista - [que] é ao mesmo tempo livre e submisso, determinado (pela exterioridade) e determinador (do que diz): essa é a condição de sua responsabilidade (sujeito jurídico, sujeito a direitos e deveres) e de sua coerência (não-contradição) que the garantem, em conjunto, sua impressão de unidade e controle de (por) sua vontade. (ORLANDI, 2001, p. 104).

Destarte, essa transparência, a objetividade na linguagem, é uma ilusão e advém do que Orlandi (1997, p. 99) denomina de "perfídia da interpretação: o fato que consiste em considerar o conteúdo (suposto) das palavras e não - como deveria ser - o funcionamento do discurso na produção dos sentidos." Essa percepção está associada ao ideológico, concebido como uma ocultação, como sentidos que serão desvelados e revelados.

Dessa forma, observa-se que toda formação ideológica comporta uma ou várias formações discursivas, que, por sua vez, "determinam o que pode e deve ser dito [...] a partir de uma posição dada numa conjuntura, isto é, numa certa relação de lugares, no interior de um aparelho ideológico, e inscrita numa relação de classes". (PÊCHEUX \& FUCHS, 1997, p. 166-7).

Fernandes (2007, p. 29) assinala que:

[...] ideologia é uma concepção de mundo de determinado grupo social em uma circunstância histórica. Linguagem e ideologia são vinculadas, esta materializa-se naquela. Ideologia é inerente ao signo em geral. Sendo assim, diante de toda e qualquer palavra pronunciada, procuraremos verificar qual (ou quais) ideologia(s) a integra $(m)$.

Assim, a ideologia, que caracteriza um discurso divergindo-o dos demais, pode ser observada em um texto sob diversos aspectos, a começar pelos sentidos produzidos em decorrência da escolha e disposição das palavras nos enunciados como ocorre no discurso jornalístico. Esses aspectos, por sua vez, são inerentes à construção de sentidos e às formações ideológicas que, historicamente, implicam em formações discursivas. É nessa perspectiva que trabalhamos a ideologia em nosso trabalho.

Posto isso, tanto o sujeito-jornalista quanto o sujeito-leitor/eleitor estão fadados a interpretar, a atribuir sentidos, de onde decorre que a interpretação não é qualquer uma, nem o sentido é qualquer um, pois os sentidos são sempre administrados pelos aparelhos de poder e pelos processos de filiação histórica dos sujeitos.

\section{O papel da mídia na sociedade}

Segundo Charaudeau (2006), processos de informar ou comunicar é uma questão de

\begin{tabular}{|l|l|l|l|l|l|}
\hline Interfaces da Educ. & Paranaíba & v. 1 & n. 2 & p. 28-43 & 2010 \\
\hline
\end{tabular}


escolha, seja de conteúdos a transmitir, seja de formas adequadas para estar em consonância com as normas do bem falar e ter clareza, especialmente dos efeitos de sentido para influenciar o outro, ou seja, a escolha de estratégias discursivas.

Para Foucault (2005b), a mídia impede a livre circulação do discurso, cuja produção acaba sendo controlada e selecionada. O que está em jogo é o "desejo" e o "poder", pois cada sociedade tem sua "política de verdade", e o discurso que prevalece é o do sujeito que detém o poder.

A mídia vende a ilusão de diversidade, de escolha, quando na verdade pode impor como o leitor tem que ser, como deve pensar, e qual escolha deve fazer. No caso das reportagens, no que tange ao desarmamento ( $\operatorname{sim} x$ não), construíram-se imagens simbólicas e recorreu-se a estratégias discursivas, induzindo, por meio da materialidade discursiva, a uma tomada de posição, ou seja, direcionando o leitor/eleitor a determinado comportamento e pensamento.

Aparentemente inofensiva e ingênua, a mídia pode trabalhar para a padronização do sujeito, por meio de técnicas, estratégias de convencimento, a exemplo das revistas Veja e Istoé; e, como assevera Foucault (2005c), essas técnicas, contínuas e ininterruptas, são como um olhar invisível que é incorporado pelos sujeitos, que começam a se autovigiar e a vigiar os outros.

Nessa perspectiva, a disciplinarização da sociedade induz os sujeitos a não serem críticos, o que muitas vezes não se percebe. Por meio desses mecanismos, o poder presente na sociedade, seja instituição midiática, social ou política, é constantemente reelaborado, organizando-se de forma a adequar-se às condições em que é produzido.

Ainda conforme Foucault (2005c), em direção à docilidade, participam colégios, hospitais, organizações militares, igreja, família, entre outras Instituições. É no micropoder que a disciplina se estabelece: há sempre lugares e regras a serem seguidas. Entre as Instituições, é necessário hoje ressaltar a mídia, que atua como "orientadora" e "formadora" de comportamentos.

A chamada mídia (meios de comunicação de massa) transformou-se em uma eficiente e concorrida forma de transmitir informações e, ao mesmo tempo, propagar ideologias para um grande número de pessoas, de classes sociais e formações diferentes. Tornou-se, assim, um modo eficaz de disseminar ideias, conceitos, isto é: por meio de determinadas produções discursivas, podem ser criadas verdades ideológicas pertinentes a determinados grupos, aos seus interesses, e, por conseguinte, intervir nas decisões e nas relações da sociedade.

\section{Mídia impressa: Veja e Istoé}

As revistas de informação são, muitas vezes, instrumentos de propagação de moda, de comportamento e de informações sobre o cotidiano da sociedade. Ademais, é necessário salientar que muitos problemas políticos, sociais e econômicos são, primeiramente, divulgados por revistas de ampla visibilidade nacional. Em primeira mão, muitos casos de corrupção e escândalos são anunciados, a exemplo da publicação de Veja acerca dos esquemas de corrupção de Fernando Collor de Melo, ex-presidente do Brasil, que foi denunciado por seu irmão Pedro Collor de Melo, em entrevista exclusiva à revista.

Além de influenciar o comportamento das pessoas, a maneira de se vestir, ou se comportar, as revistas tornam-se parte do cotidiano de uma sociedade. Por serem segmentadas e abordarem temas variados, os seus leitores esperam pelas edições, cujos assuntos geralmente se tornam alvo de comentários.

Como salienta Scalzo (2006, p. 44-45), na verdade, as revistas 
[...] podem ser chamadas de 'supermercados culturais'. Elas refletem a cultura dos lugares, o estilo de vida, e, numa sociedade consumista como a em que vivemos, não é de se estranhar que, apesar da crise econômica, as revistas que incentivam a febre pelas compras estejam em alta e representem uma tendência significativa do mercado editorial.

Por não se tratar de um veículo diário, as revistas de informação, que podem ser semanais, quinzenais ou mensais, dispõem de mais tempo para sua elaboração; logo, os redatores das matérias podem desenvolver reportagens mais completas, com mais dados e detalhes acerca do assunto abordado.

O jornalismo impresso, em especial a revista, por sua vez, como uma mercadoria qualquer, tem interesse em fazer que o seu leitor se sinta privilegiado e que estabeleça para com ela uma relação de fidelidade. Para que isso ocorra, ela se apresenta como um mosaico de informações e interesses, criando estratégias particulares para atrair o seu leitor, como exemplifica Scalzo (2006, p. 75-76):

[...] texto de revista é diferente, sim, do texto de jornal, de Internet, de televisão, de livro e de rádio. Principalmente, o texto de uma boa revista. Além de conter informações de qualidade, exclusivas e bem apuradas, o texto de revista precisa de um tempero a mais. Diferente do leitor de jornal, o de revistas espera, além de receber a informação, recebê-la de forma prazerosa. Ele quer a informação correta, simples e clara - seja o exercício para o abdômen, a receita de bolo, a nota política, o roteiro de viagem -, mas quer também um texto que não seja seco, como um aperto de mão. Resumindo: costumo dizer que, em revista, bom texto é o que deixa o leitor feliz, além de suprir suas necessidades de informação, cultura e entretenimento.

Assim, nossa escolha recaiu sobre Veja e Istoé, haja vista possuírem características análogas, como, por exemplo: são destinadas praticamente ao mesmo público-alvo, pois abordam temas variados - política, cultura, negócios, notícias nacionais e internacionais, moda, sociedade, comportamento -, têm periodicidade semanal, apresentam tamanho/formato semelhantes e também preços parecidos.

\subsection{O perfil de Veja}

A revista Veja foi lançada em 1968, nos moldes da norte-americana Time; é hoje a quarta maior revista semanal de informação do mundo e a primeira no Brasil, segundo Scalzo (2006). Pertence à Editora Abril - fundada em 1950 por Victor Civita -, é presidida por Roberto Civita, e possui uma circulação mensal com um total de 1.096 .831 exemplares, conforme a ANER (Associação Nacional de Editores), em pesquisa realizada no período de janeiro a maio do ano de 2007.

Destacamos a circulação atual (2009) de 1.098.181 exemplares, de acordo com a última pesquisa da ANER - período de janeiro a novembro de 2009 - em que demonstra a credibilidade de Veja, uma vez que continua in(formando) e vendendo o seu produto. Ou seja: o seu discurso convence e persuade o leitor.

Consoante Hernandes (2004), embora tenha necessidade do leitor, Veja possui uma posição de superioridade, apresentando-se como detentora do saber que o leitor almeja e, quase sempre, paga por isso: "A relação entre a revista - doadora de saber e poder - e um sujeito sem essas competências não é, obviamente entre iguais. VEJA constrói uma imagem de superioridade. O leitor precisa dela e nunca o inverso" (HERNANDES, 2004, p. 86).

Assine a mais lida e comentada revista brasileira e entenda melhor todos os fatos da 
semana, no Brasil e no mundo. Acompanhe de perto reportagens marcantes, entrevistas inesquecíveis, matérias que mudam o rumo dos acontecimentos. Tenha a seu lado a revista sempre abrangente, que cobre ciência, artes, cultura, política, economia, esportes e todos os assuntos que repercutem em sua vida (Abril on-line, grifo nosso).

Nessa breve exposição, a revista diz o que é, e o que quer ser. Insiste na construção de sua imagem como “indispensável” (seu slogan: indispensável) para todos os leitores que querem informação de qualidade sobre os acontecimentos no Brasil e no mundo. Com o uso do imperativo: assine, entenda, acompanhe e tenha, reforça o seu perfil de "autoritária", de exprimir uma ordem, de dar a decisão final.

Embora ela esteja tentando persuadir o leitor a fazer a assinatura, não deixa de ser superior a ele, pois, ao propor trazer assuntos variados que vão repercutir em suas vidas, produz o efeito de que tudo que o leitor deseja saber está em Veja.

Com periodicidade semanal, abordando assuntos variados, Veja é a "última a falar" sobre assuntos que são notícias em outros meios de comunicação, assim, tem uma característica distinta, que permite lançar mão das novidades relevantes sob o seu ponto de vista. Ela não omite e não faz questão de parecer neutra, visto que tem um "perfill", como postula Hernandes (2004, p. 178), "VEJA assumiu com agressividade essa missão de querer dar a palavra final sobre tudo".

Na matéria publicada no dia 5 de outubro de 2005, a revista deixou explícita sua posição em relação ao referendo das armas:

'[...] Veja alinha sete razões pelas quais julga correto votar NÃO no referendo sobre o comércio de armas de fogo convocado para o próximo dia 23. [...] Veja acredita que a atitude que melhor serve aos interesses dos seus leitores e do país é incentivar a rejeição da proposta da proibição' $(05 / 10 / 2005$, p. 77) (grifo nosso).

Veja, na tentativa de dar a palavra final sobre os acontecimentos, recorre a estratégias de persuasão para que o leitor acredite no seu discurso, isto é, não há alternativas. Seus enunciados reforçam a postura explícita da revista, com "verdades" que denotam a sua opinião, construindo, dessa maneira, fatos inquestionáveis.

O discurso jornalístico exerce uma forma de ritual, com papéis singulares, em que o jornalista é influenciado pela linha editorial e pelo perfil do veículo em que trabalha. Por meio de seu discurso, impõe, determina e utiliza estratégias de persuasão, para ditar normas e procedimentos ao leitor. No caso específico do referendo das armas, Veja induz o leitor/eleitor a votar "não", por meio da intimidação, do temor, caso não siga o que a revista propõe, como nas sequências analisadas.

\subsection{O perfil de Istoé}

A revista Istoé foi criada em 1976 e pertence à Editora Três, que é presidida por Carlos Alzugaray; sua periodicidade é semanal, abordando assuntos variados. Consoante à Editora Três, intitula-se como "ousada", "inquieta" e "ética". Está entre as dez maiores revistas de informação do mundo e afirma que esse sucesso não seria possível se não fosse a mistura de credibilidade e transparência com que se propõe apresentar os fatos, o que a torna única, com relevância fundamental na história do Brasil e do jornalismo nacional.

Ainda, de acordo com a Editora Três, também se orgulha por ter introduzido no país uma direção de arte que privilegia o dinamismo e a interatividade, além de, uma cobertura ampla de temas como comportamento e tecnologia, sendo, portanto, "leitura obrigatória entre os formadores de opinião". Tem uma tiragem mensal (até abril de 2007) de 392.694

\begin{tabular}{|l|l|l|l|l|l|}
\hline Interfaces da Educ. & Paranaíba & v. 1 & n. 2 & p. 28-43 & 2010 \\
\hline
\end{tabular}


exemplares, dos quais $88 \%$ são destinados a assinantes.

Conforme a última pesquisa da ANER, a circulação atual (2009) é de 342.694 exemplares - período de janeiro a novembro de 2009 - na qual Istoé demonstra credibilidade e aceitação de seu público-alvo.

Segundo a Editora Três, no site de apresentação de Istoé, a revista "caracteriza-se por uma linha editorial independente, jamais atrelada a grupos políticos ou econômicos".

\begin{abstract}
Está no mercado há mais de trinta anos e se consolidou como um dos veículos mais influentes do País. Foi protagonista dos mais importantes fatos políticos e sociais das últimas décadas e teve participação de destaque na redemocratização do Brasil aliás, um dos pilares básicos de ISTOÉ é a defesa intransigente do Estado Democrático de Direito [...]. ISTOÉ privilegia a reportagem e faz uma abordagem dos fatos que procura remeter o leitor além da notícia. Em decorrência disso, a revista vem ao longo dos anos colecionando uma sucessão de furos nas mais diversas editorias. (Editora3 on-line, grifo do autor).
\end{abstract}

Assim, defensora da sociedade (porta voz) como veículo influente no país, Istoé com o seu slogan "Independente", comprometida com a ética e com o jornalismo investigativo, faz questão de parecer neutra, isenta e sempre aborda os dois lados do assunto. A exemplo da matéria publicada no dia 12 de outubro de 2005, a revista tentou parecer neutra ao falar sobre o referendo das armas:

Quem luta para convencê-lo são duas Frentes Parlamentares antagônicas. A Frente Parlamentar Brasil sem Armas, defendendo o voto sim, comandada pelo presidente do Senado, Renan Calheiros (PMDB-AL), e a Frente Parlamentar pelo Direito da Legítima Defesa, defendendo o voto não, e comandada pelo deputado Alberto Fraga (PFL-DL) [...] (Istoé, 12/10/2005, p.61).

Istoé tenta convencer o leitor de que os argumentos apresentados são das Frentes Parlamentares do SIM e do NÃO. Diante disso, o seu discurso, por meio do sujeito-jornalista, na posição que exerce, conduz o seu leitor a acreditar na imagem que constrói de "neutra", de apenas "informar" os fatos.

Sabemos que não existe um discurso neutro. O jornalista Bucci ao falar sobre ética jornalística, afirma que, no fundo, dorme um problema imenso, a pretensão pela busca da "verdade" dos fatos, e questiona:

\footnotetext{
A verdade dos fatos existe? Existe um relato perfeitamente neutro e isento? A objetividade perfeita é possível? Não, não e não. A verdade dos fatos é sempre uma versão dos fatos. O relato, qualquer que seja ele, é um discurso e, como tal, inevitavelmente ideológico: mesmo quando sincera e declaradamente não opinativo, o relato jornalístico é encadeado segundo valores que obrigatoriamente definem aquilo que se escreve (BUCCI, 2004, p. 51).
}

Dessa forma, consoante à tese foucaultiana, não há uma verdade, mas várias verdades, pois o significado de verdade seria o expressado em uma determinada época, cada qual com sua verdade e seu discurso. Dito de outra maneira, cada sujeito ao ocupar uma posição, elege e interpreta de acordo com o que acredita, assim, a verdade não é absoluta, estável; é empregada nos enunciados pelos sujeitos constituídos, logo não é definitiva, inquestionável. $\mathrm{Na}$ teoria pêcheutiana, os sentidos das palavras mudam de acordo com as posições de quem as empregam e também as interpretam.

\begin{tabular}{|l|l|l|l|l|l|}
\hline Interfaces da Educ. & Paranaíba & v. 1 & n. 2 & p. 28-43 & 2010 \\
\hline
\end{tabular}




\section{O discurso de Veja e Istoé acerca do referendo das armas de 2005}

O discurso de Veja foi explícito quanto a sua posição, com a reportagem de capa, "7 Razões Para Votar NÃO. A proibição vai desarmar a população e fortalecer o arsenal dos bandidos" (Veja, 05/10/2005). Assim, a revista posicionou-se claramente a favor do "não", provocando a discussão sobre os limites entre liberdade e responsabilidade. Consoante Dines (1997, p. 40), "a informação foi trocada pelo opinionismo. E este é um convite para a irresponsabilidade e a frivolidade".

Istoé tentou manter-se na "imparcialidade", mostrando os dois lados, com a reportagem de capa "7 Razões Para Votar Sim 7 Razões Para Votar Não. Só Você decide" (Istoé, 12/10/2005). Todavia, desde o princípio, a revista primou por uma linguagem persuasiva, mesmo com o discurso "imparcial" de que só os leitores decidiriam, por meio de vários depoimentos marcados por fatos e diálogos, antes ouvidos de outras pessoas e retransmitidos, sempre acrescidos de particularidades, dando-se aí a interdiscursividade ${ }^{1}$.

Consoante Pêcheux (1994), o recorte já é uma marca de interpretação e, ao analista, é impossível, analisá-lo à distância. Destarte, o resultado obtido com a análise não é o único possível ao corpus, pois uma análise não é igual a outra, porque mobiliza conceitos distintos e isso tem resultados determinantes na descrição dos materiais. Logo, até um mesmo analista, elaborando uma questão diferente, poderia mobilizar conceitos variados, fazendo distintos recortes conceituais.

\subsection{Veja e Istoé: análise das reportagens}

(1) Nas páginas seguintes, VEJA alinha sete razões pelas quais julga correto votar NÃO no referendo sobre o comércio de armas de fogo convocado para o próximo dia 23. [...] Veja acredita que a atitude que melhor serve aos interesses dos seus leitores e do país é incentivar a rejeição da proposta da proibição (Veja, 05/10/2005, p. 77).

Na sequência discursiva (01), com os enunciados: "VEJA alinha [...] julga correto [...] acredita", fica evidente a posição de Veja acerca do referendo. A partir dessas assertivas, temos o pressuposto de que o enunciador Veja pode e deve informar; é o seu papel partilhar o "saber" com todos os "seus leitores"; por isso dirige-se a um público específico, o que compra e lê a revista, o leitor fiel, com quem ela sabe que tem credibilidade, porque é a revista mais vendida no Brasil. E o seu público-alvo vai crer no seu discurso, visto que ela detém as informações, o conhecimento, o saber e, portanto está "autorizada" a falar e persuadir o leitor para que compactue com o seu discurso.

Consoante Hernandes (2004), Veja tem um "estilo" e um "tom" de voz, e sempre dá a palavra final, ou seja, o seu discurso é autoritário. Na sequência em análise, pressupõe-se que ela investigou, analisou e se inteirou do assunto, para, em seguida, alinhar as "sete razões pelas quais julga correto votar NÃO no referendo sobre o comércio de armas de fogo convocado para o próximo dia 23". No sentido dicionarizado, a palavra "julgar", pode ser: decidir como um juiz ou árbitro, sentenciar, e é assim que Veja apresenta o seu discurso; não há outra forma, ela decidiu. Sabemos que essa revista poderia ter optado por outras palavras, mas preferiu não fazê-lo, como demonstra a assertiva: "Veja acredita que a atitude que melhor serve aos interesses dos seus leitores e do país é incentivar a rejeição da proposta da

\footnotetext{
${ }^{1}$ Segundo Fernandes (2007, p. 51) “[...] toda formação discursiva apresenta em seu interior, a presença de diferentes discursos, ao que na Análise do Discurso, denomina-se interdiscurso. Trata-se, [...] de uma interdiscursividade caracterizada pelo entrelaçamento de diferentes discursos, oriundos de diferentes momentos na história e de diferentes lugares sociais" (grifo do autor).
}

\begin{tabular}{|l|l|l|l|l|l|}
\hline Interfaces da Educ. & Paranaíba & v. 1 & n. 2 & p. 28-43 & 2010 \\
\hline
\end{tabular}


proibição." Enquanto instituição e mediadora em um processo social, coloca-se na posição de superioridade ao defender os interesses dos leitores, como ela define "seus leitores" e "do país". Temos o pressuposto de que cuida dos assuntos coletivos e, no papel de porta-voz da sociedade, informa, vigia e opina, dando ao leitor um certo "conformismo"; já que ele lhe dá sustentação, Veja indica o caminho a percorrer.

Vale dizer, como afirma Scalzo (2006), que o jornalista de jornal é distinto do jornalista de revista, pois o que escreve em jornal fala sempre para uma platéia heterogênea, sem rosto; em contrapartida, a revista entra no espaço privado, na casa dos leitores, na sua intimidade. Em outras palavras, a revista semanal de informação tem público selecionado, tem-se uma ideia melhor do grupo.

O jornalista, enquanto sujeito "oficialmente" responsável pela autoria do discurso, é, portanto, quem detém o poder ao se subjetivar, inscrevendo seu dizer no intervalo que há entre o dizer da política, da mídia, do leitor e do dono da revista. Nesse caso, a função de ator político desempenhada pelo jornalista de Veja não é ligada a sua posição pessoal, mas a uma ideologia profissional. Foucault (2005b, p. 9) assinala que, "não se tem o direito de dizer tudo, [...] não se pode falar de tudo em qualquer circunstância, [...] qualquer um, enfim, não pode falar de qualquer coisa". Por conseguinte, não é dono do seu dizer, ou seja, não é totalmente livre para dizer o que bem entende.

Diante disso, o sujeito-jornalista é influenciado pela linha editorial e pelo perfil do veículo em que trabalha, ou seja, por Veja, que é detentora do saber. Com o poder que lhe é conferido, assume o papel de porta-voz, fala em nome dos "seus leitores", acreditando defender os seus interesses.

Em Vigiar e Punir, Foucault (2005c) assevera que o corpo, com sua singularidade, articula-se com outros corpos por meio da dinâmica do movimento, como o comportamento, para que possa ser controlado num determinado tempo e espaço, com o objetivo de produzir mais e melhor. Porém é preciso que todos os corpos conheçam os mesmos sinais, para que haja harmonia de gestos e eficiência na produção final.

Logo, para que o enunciador Veja tenha êxito na sua estratégia de persuasão, é necessário que o leitor partilhe dos mesmos valores, acredite no seu discurso; só assim ele optará pelo "não", em que a revista acredita; além disso, continuará comprando, correspondendo à ideologia capitalista e consumista.

(02) [...] O referendo é um despiste, uma tentativa de mudar de assunto, de desviar a atenção das pessoas do mal que realmente as atormenta: o banditismo. Pior ainda. Com uma possível vitória do SIM não terá efeito positivo algum - ao contrário, vai ajudar a aumentar ainda mais o poder de fogo dos bandidos -, as pessoas vão se sentir culpadas pelos crimes que continuarão acontecendo. (Veja, 05/10/2005, p. 78).

Nesse recorte, o discurso da revista é contornado pela modalidade negativa, em que atuam operadores linguísticos de negação: "pior ainda", "não", "ao contrário", transmitindo, assim, a sensação de violência que vai continuar, de dificuldades, e o risco que as pessoas correrão se optarem pelo "sim", isto é, se discordarem do que ela diz. Como detentor do saber, o enunciador Veja, na tentativa de controle de decisões, exerce poder enquanto mediador em um processo social.

Utilizando-se de termos com carga negativa em seu discurso, leva o leitor/eleitor a crer que a melhor opção é o "não". Para tanto, a revista utiliza estratégias discursivas de instituição do medo, temor, como vemos no enunciado "ao contrário, vai ajudar a aumentar ainda mais o poder de fogo dos bandidos", e de intimidação: "O referendo é um despiste, uma tentativa de mudar de assunto, de desviar a atenção das pessoas do mal que realmente as atormenta: o banditismo. Pior ainda. Com uma possível vitória do SIM não terá efeito positivo algum - as

\begin{tabular}{|l|l|l|l|l|l|}
\hline Interfaces da Educ. & Paranaíba & v. 1 & n. 2 & p. 28-43 & 2010 \\
\hline
\end{tabular}


pessoas vão se sentir culpadas pelos crimes que continuarão acontecendo". A revista elabora uma resposta a quem ousa votar "sim". Veja pretende provar que não há possibilidade da escolha do "sim". O caminho (pensamento) único já está definido.

Essa sequência explicita o papel político da revista: regular a legitimidade das organizações sociais a partir da visão de mundo e do pensamento único institucionalizado em suas páginas. A revista também poderia ter optado por outro discurso, todavia funciona como uma sociedade disciplinar. Foucault (2005c, p. 118), ao analisar o processo de "disciplinarização" da sociedade, afirma que "[...] é dócil um corpo que pode ser submetido, que pode ser utilizado, que pode ser transformado e aperfeiçoado", visto que o ser humano (corpo) está submetido a limitações, proibições e obrigações, quer dizer, a uma disciplina.

Assim, Veja controla o que deve ser dito, escutado, num esquema de docilidade, pois o leitor que tem acesso à reportagem seguirá o caminho proposto pela revista, haja vista ele crer no seu discurso, pois é a revista de maior tiragem no Brasil.

Nas análises seguintes, confira as sequências discursivas da revista Istoé.

(03) Nas páginas a seguir, ISTOÉ apresenta sete razões para se optar pelo sim - ou seja, pela proibição - e mais sete para se optar pelo não - ou seja, pela manutenção da venda de armas e munições. Não são razões comuns, mas sustentadas pelo testemunho de 14 pessoas que tiveram suas vidas radicalmente alteradas quando um gatilho foi acionado. (Istoé, 12/10/2005, p. 61).

Na construção escolhida pela revista, por meio de um paralelismo rigoroso - não fosse o quantificador "mais", na segunda parte do enunciado -, o enunciador procura produzir o efeito de imparcialidade: independente da posição da revista (aparentemente neutra), ela apresenta o mesmo número de razões para cada "posicionamento" (SIM X NÃO).

Intencional ou inconscientemente, no entanto, o "sim" vem em primeiro lugar e o "mais" trai o efeito pretendido: há 7 razões para o "sim", mas se você , leitor, não quiser votar "sim", há mais sete (mais relevantes).

Com o enunciado: "ISTOÉ apresenta sete razões para se optar pelo sim - ou seja, pela proibição - e mais sete para se optar pelo não - ou seja, pela manutenção da venda de armas e munições", já de início instaura-se a polêmica em relação a sua concorrente Veja, quando recorre ao mesmo número, o sete, utilizado por Veja na edição anterior.

Veja (01) alinhara sete razões para votar "não"; a Istoé, cujo slogan é "Independente", há o não-dito: sua concorrente não é independente. Para tentar parecer "isenta", assim se pronuncia como se conhecesse seu leitor. Ao contrário de sua concorrente, não opina, não precisa defender uma posição, por isso mostra os dois lados, o que a deixa na aparente posição de "neutra" e "imparcial" em relação aos fatos narrados e, dessa maneira, o seu púbico-alvo vai crer no seu discurso.

No entanto, para a $\mathrm{AD}$, esse distanciamento dos fatos não ocorre, porque não há um sentido já fixado, prévio, antecipado no dizer, como Istoé quer demonstrar em seu discurso. Essa isenção é impossível, pois o sentido de uma palavra, ou proposição, não existe por si só, mas é determinado pelas posições ideológicas dispostas no processo sócio-histórico em que elas são reproduzidas. Em outras palavras, o sentido não existe como produto acabado; está sempre em movimento; assim, só pode ser constituído em relação às condições de produção de um determinado enunciado, porque muda de acordo com a formação ideológica de quem o (re) produz, bem como de quem o interpreta.

Como estratégia de persuasão, a revista recorre ao testemunho de pessoas que tiveram suas vidas alteradas quando um gatilho foi acionado, uma estratégia muito solicitada pelas mídias, e salienta que não são motivos comuns: "Não são razões comuns, mas sustentadas pelo testemunho de 14 pessoas que tiveram suas vidas radicalmente alteradas quando um

\begin{tabular}{|l|l|l|l|l|l|}
\hline Interfaces da Educ. & Paranaíba & v. 1 & n. 2 & p. 28-43 & 2010 \\
\hline
\end{tabular}


gatilho foi acionado". Charaudeau (2006, p. 53), ao falar de quem informa e quando o informante é uma testemunha, assinala que ele desempenha o papel de "portador da verdade", porque não há outro objetivo em sua fala a não ser dizer o que viu e ouviu. Logo, "ele não é suspeito de utilizar alguma estratégia de ocultamento, pois é considerado completamente ingênuo, isto é, desprovido de qualquer tipo de cálculo, quanto à utilização de seu testemunho: ele só poderia dizer a verdade".

Por meio do discurso de Istoé, depreendemos que os sentidos no discurso jornalístico podem estar ocultos ou silenciados, por meio de um processo de escolha, seleção e edição que vai nortear leitores segundo a visão seletiva dos interesses por trás dos processos de edição: induzir o leitor a crer no seu discurso de imparcialidade, afinal, catorze pessoas testemunharam, todos os lados foram ouvidos.

Portanto, na cadeia de produção da notícia, várias vozes vão-se justapondo, sendo recortadas, coladas, de maneira implícita ou não, como, por exemplo, os registros dos dizeres escritos e falados pelos repórteres, a fala dos depoimentos dos entrevistados (testemunhas) e os ajustes finais do editor.

O discurso jornalístico informa o leitor, o que corrobora para comprovar de que essa informação já vem regulada e formatada por meio de regras e procedimentos. Istoé, na sequência analisada, recorre a estratégias de persuasão, com o objetivo de modificar o comportamento do leitor e fazer que compartilhe do mesmo discurso, ou seja, projetando a imagem de "neutralidade" e "imparcialidade", "o mito" de isenção do/no jornalismo.

(04) São histórias quase sempre dramáticas que emolduram posições surpreendentes, aparentemente contraditórias, mas sempre elucidativas. Que certamente vão contribuir com sua escolha. Apenas contribuir, porque a decisão é sua, apenas sua. (Istoé, 12/10/2005, p. 61).

Na sequência discursiva em análise, é possível verificar que o enunciador Istoé quer fazer-crer nas regras de imparcialidade: todos os lados foram ouvidos. A partir do testemunho de pessoas que passaram por situações dramáticas, e, por conseguinte, tiveram suas histórias narradas, assim, Istoé ocupa a posição de somente informar e narrar os fatos.

A revista, além de produzir efeito de verdade objetiva ao transmitir a opinião do outro, com a aparência de distanciamento, evita arcar com a responsabilidade do que é dito, ou seja, o saber é das fontes. Há um afastamento que pressupõe um "não fomos nós que dissemos", são cidadãos comuns (como você leitor/eleitor), várias vozes foram ouvidas, e isso prova uma verdade geral; a opinião dos entrevistados confirma essa objetividade. Em outras palavras, ouvimos os dois lados, não interferimos na escolha; ao leitor/eleitor cabe o livre-arbítrio.

No enunciado "Que certamente vão contribuir com sua escolha. Apenas contribuir, porque a decisão é sua, apenas sua", ao utilizar o operador "certamente", Istoé demonstra uma certeza de que seus argumentos são incontestáveis, ou seja, não há dúvidas a despeito de suas histórias, em que ela, com o saber e o poder, vai contribuir para que o leitor/eleitor faça a melhor escolha, mas é responsabilidade do leitor fazer a escolha, depende dele, só dele. Ao empregar "com sua", "a decisão é sua, apenas sua", a revista instaura uma aproximação, estabelece uma certa intimidade; em contrapartida, sugere um distanciamento e a imparcialidade; visto que não tomou partido, isso caberá ao leitor/eleitor fazer. Mais uma vez, a revista comprova a estratégia de persuasão da imparcialidade e objetividade, para convencer o leitor a crer no seu discurso.

Embora Istoé dê a entender que não influenciará na escolha do leitor, como no enunciado: "Apenas contribuir, porque a decisão é sua, apenas sua", pressupõe-se que só depois de se inteirar das histórias "dramáticas", "surpreendentes", "aparentemente contraditórias", "mas sempre elucidativas", apresentadas pela revista, é que ele poderá fazer a 
melhor escolha, pois agora possui o saber, que só foi possível por meio do saber doado pela revista.

Como nos lembra Foucault (2005c), o poder disciplinar faz-se presente, um tanto modesto, desconfiado, mas constante, de forma autorizada ou não, e os corpos permitem essa manipulação. Dito de outra maneira, o saber que a revista doa é incontestável; assim, o leitor fará a melhor opção com base no que ela diz.

Dessa forma, posiciona-se com o poder de informar e doar o saber. Também, quando defende os dois lados, "sim" e "não", baseada em depoimentos de testemunhas e suas histórias, Istoé constrói uma imagem de "neutralidade" e "imparcialidade": apenas informa, o que lhe confere maior credibilidade ao apresentar os fatos e, portanto, induz o leitor a acreditar no seu discurso de "imparcialidade". Ademais, continuará falando em nome da sociedade, dos interesses dos cidadãos, do seu público-alvo, de maneira clara, objetiva e imparcial.

\subsection{Veja e Istoé: análise das "cartas"}

Consideramos relevante recortarmos alguns fragmentos da "Seção Cartas" de ambas as revistas, sobre o mesmo tema - o referendo das armas -, para evidenciar quem são os seus leitores e como são vistos pelas revistas.

Analisamos quatro fragmentos de Veja e, posteriormente, quatro fragmentos de Istoé.

Na seção "Carta ao Leitor" do dia 12 de outubro de 2005, a revista comemora o recorde de cartas enviadas à redação, pela publicação anterior, cuja capa foi: "7 Razões Para Votar Não - A proibição vai desarmar a população e fortalecer o arsenal dos bandidos" $(05 / 10 / 2005)$ :

(05) Sintonia com os leitores - Além de bater o recorde de cartas enviadas à redação, a reportagem de capa da semana passada conseguiu uma confortável maioria de aprovação entre seus leitores - 59\% ficaram a favor da tomada de posição de VEJA contra a proibição da comercialização de armas, enquanto $32 \%$ não se convenceram dos argumentos apresentados [...]. (Veja, 12/10/2005, p. 9).

A revista denota uma satisfação em dizer que os leitores aprovam seus argumentos e, por meio dos seus enunciados - "O NÃO venceu entre os leitores de VEJA" -, desvela a imagem que tem de seu leitor, isto é, leitores interessados em leituras diferenciadas, "por um algo a mais", sobre fatos polêmicos, que sobretudo já foram noticiados por outras mídias. Assim, ao ouvir determinado discurso, Veja imagina um leitor que já possui um saber construído sobre o assunto, visto que ele não está ouvindo pela primeira vez aquele discurso; logo, deseja uma postura distinta.

Nas próximas sequências (06 a 09), do dia 12 de outubro de 2005, os leitores discorrem sobre a reportagem publicada na Veja, edição 1925, de 5 de outubro, com o título "Referendo da Fumaça".

(06) "VEJA, pioneira nos grandes debates nacionais e corajosa como sempre, marca sua posição diante da questão do desarmamento [...]".

(07) "Felizmente, VEJA esclarece todas as dúvidas para o cidadão comum [...]”.

(08) "Parabéns a revista VEJA por romper bloqueios de vários veículos de comunicação e realizar uma reportagem bastante clara $[\ldots]$ ”. 
É mister destacar que não estamos contrários à linha editorial da revista, e nem tampouco tomando juízos de valor acerca do tom interpretativo e opinativo que Veja utiliza em seus enunciados. A nós interessa, sobretudo, mostrar como a revista recorre a estratégias discursivas de autoridade e superioridade.

Ao "selecionar" as cartas para a publicação, Veja mostra a sua "autoridade" e "superioridade". Nos recortes apresentados, verificamos o quanto o leitor acredita "na verdade" que está posta, sem rodeios, sem questionamentos. Embora a revista deixe clara sua opinião, mantendo a conduta de direcionar os leitores segundo sua exposição, receitando os caminhos a serem percorridos, depreendemos que há uma aceitação por parte de seu públicoalvo, o que nos leva a dizer que o leitor de Veja compactua com o seu discurso, dialoga com a revista, como é possível observar em: "VEJA, pioneira [...] corajosa como sempre", "Parabéns a revista VEJA [...]", "Felizmente, VEJA esclarece [...]", o que confirma a proximidade buscada pelo enunciador Veja.

Dessa forma, a revista, nas palavras de Scalzo (2006, p.12), estabelece um contato, um encontro entre um editor e um leitor, "um fio invisível que une um grupo de pessoas e, nesse sentido, ajuda a construir uma identidade [...] ou seja, dá a sensação de pertencer a um determinado grupo". E assevera que os leitores, por pertencerem a este ou àquele grupo, "gostam de andar abraçados às suas revistas - ou de andar com elas à mostra", para que todos vejam, e, assim saber a qual grupo eles pertencem.

Essa (ilusão da) neutralidade, recorrente na análise das sequências discursivas, também é "mostrada" na "Seção Cartas", da revista Istoé, em que os leitores (aqueles cujas cartas foram escolhidas) apresentam-se identificados com o discurso da revista, com seus pretensos traços de "imparcialidade" e "neutralidade".

No próximo segmento, temos mais quatro recortes do dia 19 de outubro de 2005, com comentários oriundos da matéria publicada no dia 12 de outubro de 2005, cujo título foi "Sim? Não? Só você decide". Ali observamos o deleite do leitor, ao deparar com as notícias sobre o referendo das armas e, por conseguinte, manifestar a aceitação do discurso proferido por Istoé, como ético e imparcial.

Ademais, retoma o já-dito: o papel dos meios de comunicação é informar e não induzir. Vale ressaltar que, de forma explícita, indica e critica a "outra" revista, que sempre denotaria parcialidade em suas matérias, deixando evidente a concorrência e a disputa por leitores. Revela-se uma certa "rivalidade" na defesa da revista semanal "preferida", "eleita" e, logo, sua adesão ao discurso da revista, o que nos lembra a jornalista Scalzo (2006), ao falar dos laços afetivos que as revistas criam com o leitor.

(09) "Não sou assinante desta revista, mas comprei um exemplar na banca e quero, por meio desta, parabenizá-los pela alta qualidade jornalística da matéria sobre o desarmamento. Vocês apostaram na inteligência do leitor e não na propaganda barata da 'outra' revista de circulação nacional. É do jornalismo que a revista ISTOÉ faz que o Brasil precisa. Parabéns" (grifo nosso).

(10) "Diferente de alguns órgãos que claramente demonstram diariamente em suas matéria e editoriais sua tendência e posição, ISTOÉ mais uma vez nos presenteia com excelente reportagem sobre o Referendo do desarmamento, na qual, como leitor, pude analisar os prós e os contras. Acho que a imprensa nacional deveria seguir o exemplo tratando o assunto com isenção. Parabéns" (grifo nosso).

(11) "A revista deu uma lição de dignidade e imparcialidade, quando se trata de assuntos polêmicos, políticos e de interesse de toda a coletividade. Fez realmente o que deveria ser feito. Mostrar os dois lados. Não como Veja que sempre traz reportagens com total parcialidade, como no caso das Sete Razões para Votar Não. 
Deveria estar defendendo o interesse de alguém" (grifo nosso).

Importa destacar, aqui, que o nome da concorrente é explicitado e, ao explicitar-se, é, no conjunto das relações textuais, qualificado por negação, como não digno, não imparcial, que a Istoé dispõe do apoio de seu leitor para criticar explicitamente a "outra" revista e também ratificar sua "dignidade" e "imparcialidade". Ao conceber a "palavra" ao outro, mantém-se (aparentemente) neutra.

(12) "Parabenizo a ISTOÉ pela aula de ética jornalística ao mostrar de maneira imparcial razões para que o eleitor decida a melhor opção de voto no Referendo das Armas. Esse é o verdadeiro dever da imprensa: informar e não induzir" (grifo nosso).

Embora, tenhamos apresentado somente algumas sequências discursivas pertinentes ao dizer dos leitores de Istoé, pudemos, a partir delas, dizer que a revista escreve para um público-alvo que acredita no seu discurso de "imparcialidade", que não opina e sempre mostra os dois lados da questão. A opinião será sempre do leitor, ela apenas "informa" e a decisão final caberá ao leitor.

\section{Considerações finais}

As análises nos permitiram verificar que, Veja e Istoé, reafirmam a sua autopromoção: informam os fatos e cumprem o seu papel de mediadoras e formadoras de opiniões. No caso de Veja, que, desde o princípio opina e utiliza estratégias discursivas para convencer o leitor/eleitor a crer no seu discurso, não deseja ser imparcial e neutra, uma vez que não é o seu perfil. O seu discurso é embasado em estatísticas para desqualificar o governo e a segurança pública no país, e com o discurso autoritário sugere o que fazer. Istoé, por sua vez, delega voz aos entrevistados, que também criticam o governo e suas medidas, e assim continua com o pretenso discurso da "neutralidade" e "imparcialidade", pois procura não se envolver, apenas informar os fatos.

Por meio dos discursos dos leitores de Veja e Istoé, na "Seção Cartas", constatamos como eles se identificam com os discursos das revistas e como elas denotam conhecer seu público-alvo. No que concerne a Veja, seu público-alvo partilha de seu discurso, como nos recortes apresentados. Istoé também denota conhecer o seu público-alvo e conta com sua fidelidade, visto que está permeada de elogios no que concerne à prática jornalística adotada pela revista, como demonstram os recortes que destacamos. Recortes estes que se apresentam sob o manto da "imparcialidade" e "neutralidade", somente no papel de informante, sem induzir a uma tomada de posição.

A "Seção Cartas" funciona como um termômetro para que Veja e Istoé avaliem o próprio desempenho, uma estratégia que utilizam para saber a opinião dos leitores, seu público-alvo, e assim poderão manter ou modificar as estratégias de persuasão de seus discursos e, portanto, firmarem os laços com os seus leitores fiéis, o que lhes dá sustentação e direção para as próximas publicações. As revistas têm credibilidade e, com seus discursos persuasivos, mantêm um público-alvo fiel que acredita neles, nas imagens que constroem e projetam de um para o outro.

Acreditamos que, à luz das informações teóricas apresentadas, pudemos, a partir da análise, compreender melhor alguns conceitos da Análise do Discurso. Nesse sentido, destacamos também que o estudo da $\mathrm{AD}$ possibilita uma reflexão de que podemos entender além das palavras ou imagens divulgadas, e ter uma dimensão mais elaborada daquilo que vemos, ouvimos, lemos e/ou a que assistimos. Por conseguinte, analisar o discurso é

\begin{tabular}{|l|l|l|l|l|l|}
\hline Interfaces da Educ. & Paranaíba & v. 1 & n. 2 & p. 28-43 & 2010 \\
\hline
\end{tabular}


interpretar os sujeitos falando e suas condições de produção, porquanto, os sentidos das palavras no discurso não são fixos, estáveis, são produzidos mediante os lugares ocupados pelos sujeitos em interlocução.

\section{Referências Bibliográficas}

BUCCI, Eugênio. Sobre ética e imprensa. 2. ed. São Paulo: Companhia das Letras, 2004.

CARTAS. Desarmamento. IstoÉ, no 1879, p. 14-15, 19 out. 2005.

CARTA ao leitor: sintonia com os leitores. Veja, edição 1926, ano 38, n 41, p. 9, 12 de out. 2005.

CARTAS. Referendo das armas. Veja, edição 1926, ano 38, nº 41, p. 32-33, 12 de out. 2005.

CHARAUDEAU, Patrick. Discurso das mídias. Tradução de Ângela S. M.Corrêa. São Paulo: Contexto, 2006.

DINES, Alberto. O jornalismo brasileiro visto pelos correspondentes estrangeiros. In: DINES, A.; VOGT, C.; MELO, J. M. A imprensa em questão. Campinas-SP: Unicamp, 1997.

FERNANDES, Cleudemar Alves. Análise do discurso: reflexões introdutórias. 2. ed. São Carlos: Claraluz, 2007.

FERREIRA, A. B. H. Novo dicionário Aurélio eletrônico. 3. ed. 1. impressão. Positivo, 2004.

FOUCAULT, Michel. Arqueologia do saber. Tradução de L. F. Baeta Neves. 7. ed. Rio de Janeiro: Forense Universitária, 2005a (1969). $(1971)$.

. A ordem do discurso. Tradução de L. F.de Sampaio. 12 ed. São Paulo: Loyola, 2005b

.Vigiar e punir: nascimento da prisão. Tradução de Raquel Ramalhete. 30. ed.

Petrópolis: Vozes, 2005c.

FILHO, Aziz; FONSECA, Celso; HOLLANDA, Eduardo; CARUSO, Marina. Sim? Não? Só você decide. IstoÉ, no 1878, p. 60-70, 12 de out. 2005.

HERNANDES, Nilton. A revista Veja e o discurso do emprego na globalização: uma análise semiótica. Salvador: Edufba; Maceió: Edufal, 2004.

KLINTOWITZ, Jaime. Referendo da Fumaça. Veja, edição 1925, ano 38, nº 40, p. 76-88, 5 de out. 2005.

ORLANDI, Eni. As formas do silêncio: no movimento dos sentidos. 4. ed. Campinas - SP: Unicamp, 1997.

Discurso e texto: formulação e circulação dos sentidos. Campinas: Pontes, 2001. Análise de discurso: princípios e procedimentos. 6. ed. Campinas, SP: Pontes, 2005.

\begin{tabular}{|l|l|l|l|l|l|}
\hline Interfaces da Educ. & Paranaíba & v. 1 & n. 2 & p. 28-43 & 2010 \\
\hline
\end{tabular}


PÊCHEUX, Michel. Ler o arquivo hoje. In: ORLANDI, E. (Org.). Gestos de leitura: da história no discurso. Campinas - SP: Unicamp, 1994, p.55-64.

. Semântica e discurso: uma crítica à afirmação do óbvio. Tradução de E. P. Orlandi. 3. ed. Campinas: Unicamp, 1997.

PÊCHEUX, Michel; FUCHS, Catherine. A propósito da análise automática do discurso: atualização e perspectivas. Tradução de Péricles Cunha. In: GADET, F; HAK, T. (Org). Por uma análise automática do discurso: uma introdução à obra de Michel Pêcheux. 3. ed. Campinas: Unicamp, 1997.

PRELLVITZ, Tani Jacobson. Estrangeiro ou imigrante: o discurso da imprensa construindo a (in)aceitabilidade. 2006. 162 f. Dissertação (Mestrado em Estudos da Linguagem) Universidade Federal do Rio Grande do Sul.

RIBEIRO, José Hamilton. O jornalismo brasileiro visto pelas corporações. In: DINES, A.; VOGT, C.; MELO, J. M. A imprensa em questão. Campinas-SP: Unicamp, 1997.

SCALZO, Marília. Jornalismo de revista. 3. ed. São Paulo: Contexto, 2006.

SITE da Associação Nacional de Editores de Revistas. Disponível em:

$<$ http://www.aner.org.br/Conteudo/1/artigo42424-1.asp>. Acesso em: 2 abr. 2007.

SITE da Associação Nacional de Editores de Revistas. Disponível em:

$<$ http://www.aner.org.br/Conteudo/1/artigo42424-1.asp>. Acesso em: 6 jun. 2010.

SITE da Diretoria de Publicidade da Editora Três. Disponível em:

$<$ http://editora3.terra.com.br/publicidade_portugues/istoe/apresentacao.htm>. Acesso em: 15 jun. 2007.

SITE da Diretoria de Publicidade da Editora Três. Disponível em:

$<$ http://editora3.terra.com.br/publicidade_portugues/istoe/apresentacao.htm $>$. Acesso em: 6 jun. 2010.

SITE da Revista Veja. Disponível em:

$<$ http://www.assineabril.com.br/index.jsp?projeto=901\&campanha=LRC4\&id=homeselo1 $>$. Acesso em: 15 jun. 2007.

ZANDWAIS, Ana. A forma sujeito do discurso e suas modalidades de subjetivação: um contraponto entre saberes e práticas. In: INDURSKY, Freda; FERREIRA, Maria C. L (Org.). Michel Pêcheux e a análise do discurso: uma relação de nunca acabar. São Carlos: Claraluz, 2005. 